\title{
Reduction of sodium and increment of calcium and $\omega-3$ PUFA in dry fermented sausages: effects on the mineral content, lipid profile and sensory quality
}

Mikel García-Íñiguez de Ciriano ${ }^{1}$, Izaskun Berasategi ${ }^{1}$, Íñigo Navarro-Blasco ${ }^{2}$, Iciar Astiasarán $^{1}$, Diana Ansorena ${ }^{1 *}$

\footnotetext{
${ }^{1}$ Department of Nutrition, Food Science, Physiology and Toxicology, Faculty of Pharmacy, University of Navarra, Irunlarrea s/n, 31008-Pamplona, Spain.

${ }^{2}$ Department of Chemistry and Soil Science, Faculty of Sciences, University of Navarra. Irunlarrea s/n, 31008-Pamplona, Spain.
}

\footnotetext{
*Corresponding author: Tel.: +34 948425600 (extn. 6263); Fax: +34 948425649 . E-mail address: dansorena@unav.es
} 


\begin{abstract}
A combined technological approach was applied in the development of healthier dry fermented sausages: a partial substitution of the pork back fat by pre-emulsified linseed oil and a partial replacement of sodium chloride with calcium ascorbate at two different levels leading to low amounts of salt (14gSalt \& $10 \mathrm{gSalt})$. The developed products showed adequate results for $\mathrm{a}_{\mathrm{w}}$ and $\mathrm{pH}$, and low lipid oxidation values. The lipid modification allowed the new products to be claimed as "source of $\omega-3$ PUFA". Simultaneously, reductions of $38 \%$ and $50 \%$ in the sodium content were achieved in the $14 \mathrm{gSalt}$ and $10 \mathrm{gSalt}$ formulations respectively, compared to the control products (26 g salt), so that "reduced sodium" and "high calcium" could be also claimed.

The instrumental analysis of color and texture and the sensory studies demonstrated that the organoleptic quality of the new formulations was similar to that of traditional products.
\end{abstract}

\title{
Keywords:
}

Linseed oil; Sodium reduction; Calcium ascorbate; Sensory analysis; Texture; Color. 


\section{INTRODUCTION}

Two relevant public health issues are dealt in this paper: the reduction of dietary salt and the improvement of dietary food lipid profile. These are major concerns of a large number of organizations due to their influence on cardiovascular health. The World Health Organization ${ }^{1}$ recommends that daily diets should provide sufficient intake of polyunsaturated fatty acids (PUFA) (6-10\% of daily energy intake), with an adequate proportion of $\omega-3$ PUFA (1-2 \% daily energy intake). In this sense, EFSA has proposed setting the labelling reference intake for ALA in $2 \mathrm{~g} /$ day. ${ }^{2}$ Dietary salt is pointed out as the major cause of raised blood pressure, causing hypertension and raising the cardio vascular diseases risk and its reduction implies lowers blood pressure, thereby, reducing blood pressure-related diseases. ${ }^{3}$ In consequence, WHO recommends reducing dietary daily intake of sodium to $2 \mathrm{~g}$ ( $5 \mathrm{~g}$ salt), and several countries have developed national programs to reach this aim. ${ }^{4}$

Meat and meat products are recognized in the Western diet as the main source of essential amino acids, high biological value proteins, bioavailable iron, other minerals and vitamin $\mathrm{B} .{ }^{5}$ In spite of these nutritional benefits, an excessive intake of meat products is not recommended, as they have been associated with an increased risk of attracting chronic diseases. ${ }^{6}$ The meat products are, in industrialized countries, among the major sources of dietetic sodium, in the form of sodium chloride. In consequence, it is of a great importance to develop technological strategies for obtaining new meat products able to maintain the advantages of traditional formulations reducing, at the same time, the negative aspects currently attributed to them.

With this aim, several modifications on the lipid profile of meat products have been carried out by means of partial back fat replacements with different pre-emulsified oils, such as linseed, fish and algae oils, obtaining healthier products with a higher 
nutritional value and similar sensory acceptance than traditional formulations. The higher susceptibility to lipid oxidation of these new formulations has been controlled through the use of significant amounts of antioxidants, such as butylhydroxyanisole (BHA) or natural antioxidants obtained from different sources. ${ }^{7-10}$

Reducing salt seems, however, a challenge for the meat industry, as it plays an essential role in terms of taste, stability, safety and protein binding ability. ${ }^{4,11,12}$ All strategies towards the reduction of the sodium content should take into account all these functions. ${ }^{13}$ Mixtures of different salts such as $\mathrm{KCl}, \mathrm{CaCl}_{2}$ or $\mathrm{MgCl}_{2}$ have been used in cooked, fresh and cured meat products. ${ }^{14-17}$ Previous works have used calcium ascorbate $(\mathrm{CaAs})$ as a partial salt replacer in traditional dry fermented sausages ${ }^{18}$ and in emulsiontype sausages. ${ }^{19}$ This seems to be a good strategy from the nutritional point of view, as CaAs has been proved to provide highly bioavailable calcium, compared to other salts. ${ }^{20}$ Also, it has been established that the calcium fortification in processed meat products could be a good matrix for improving the calcium intake in the diet of special population groups. ${ }^{21}$

In this paper, a simultaneous strategy to decrease the salt content by using CaAs and to improve the lipid fraction by increasing the $\omega-3$ PUFA content is assayed in dry fermented sausages. This approach has been previously attempted in other type of meat products, but not in cured ones, that are characterized by a particular production procedure, including a fermentation and desiccation process, totally different from other meat derivatives. Thus, in beef patties, ${ }^{22}$ combined a partial animal fat substitution with seaweed and olive oil with a salt content reduction. Also, ${ }^{23}$, developed cooked sausages with less fat and salt content by means of the use of kappa-carrageenan, gellan gum and other salts, as potassium, magnesium and calcium chloride. 
In this context, the aim of this study was to develop a new formulation of dry fermented sausages including linseed oil as a source of $\omega-3$ fatty acids and CaAs as a partial replacer of $\mathrm{NaCl}$. Technological, nutritional and sensory evaluation of the resulting products has been carried out. The important role of both fat and salt in the technological and sensory viability of dry fermented sausages makes this simultaneous approach a challenging strategy, not previously assayed.

\section{MATERIALS AND METHODS}

\section{Sausage formulation and processing}

Three formulations of dry fermented sausages (Chorizo de Pamplona) were prepared according to the general procedure described by ${ }^{24}$. The control batches were formulated as a typical recipe for this type of fermented products $(75 \%$ lean pork meat \& $25 \%$ pork back fat), whereas the modified formulations incorporated changes that affected both the lipid and the mineral fractions. In the modified formulations, a $25 \%$ of the total pork back fat content was substituted by an emulsion containing linseed oil (Biolasi, Productos Naturales. Guipúzcoa, Spain) and also 200 ppm of butylhydroxyanisole (BHA) were added. The emulsion was prepared mixing, for two minutes, eight parts of hot water with one part of isolated soy protein and then with ten parts of oil for other three minutes. The control batches incorporated $26 \mathrm{~g}$ of salt $(\mathrm{NaCl})$ per $\mathrm{kg}$ of meat batter, whereas the other two batches incorporated $14 \mathrm{~g} / \mathrm{kg}$ of salt (14gSalt) and $10 \mathrm{~g} / \mathrm{kg}$ of salt (10gSalt), respectively. In these two formulations, CaAs was added at an equivalent ionic strength to the replaced salt. Thus, 29 and $38.9 \mathrm{~g} / \mathrm{kg}$ of CaAs were added in $14 \mathrm{gSalt}$ and $10 \mathrm{gSalt}$ batches, respectively. 
The following ingredients per kilogram of meat mixture were added to all formulations: red pepper $30 \mathrm{~g}$, dextrin $15 \mathrm{~g}$, lactose $10 \mathrm{~g}$, powdered milk $12 \mathrm{~g}$, dextrose $5 \mathrm{~g}$, sodium ascorbate $0.5 \mathrm{~g}$, sodium caseinate $10 \mathrm{~g}$, garlic $3 \mathrm{~g}$, polyphosphates $2 \mathrm{~g}$, curing agents (a mixture of $\mathrm{NaCl}$, preservatives sodium nitrites -E-250-, sodium nitrate -E-252- and antioxidant sodium citrate-E-331-) $3 \mathrm{~g}$, ponceau 4R (E-124) $0.15 \mathrm{~g}$. Sausages were fermented and ripened for 30 days under conditions described by ${ }^{24}$ in a drying chamber (STA model W 80XDHG-VEH, Noain, Spain). The analysis was carried out at the end of the ripening process.

\section{Chemical analysis}

The water activity $\left(\mathrm{a}_{\mathrm{w}}\right)$ was analyzed using a Novasina aw-Center, (Novasina AG., Lanchen; Switzerland) and $\mathrm{pH}$ was measured directly in the sausage with a $\mathrm{pH}-$ meter micropH 2000 using a Needle electrode (Crison Instrument S.A., Barcelona). Ash determination was done according to the AOAC official method. ${ }^{25}$ Total fat was determined by an extraction with petroleum ether. ${ }^{26}$

TBARS value was determined according to ${ }^{27}$. Results are shown in $\mathrm{mg}$ Malondialdehyde (MDA)/kg sample.

The method of ${ }^{28}$ was used for the extraction of lipids. Fatty acids were determined in the lipid extract by gas chromatography. Boron trifluoride/methanol was used for the preparation of fatty acid methyl esters. ${ }^{29}$ A Perkin-Elmer Autosystem XL gas chromatograph fitted with a capillary column $\mathrm{SP}^{\mathrm{TM}}-2560(100 \mathrm{~m}$ x $0.25 \mathrm{~mm} \times 0.2$ $\mu \mathrm{m})$ and flame ionization detection was used. The temperature of the injection port was $250{ }^{\circ} \mathrm{C}$ and of the detector was $260^{\circ} \mathrm{C}$. The oven temperature was programmed at 175 ${ }^{\circ} \mathrm{C}$ during $10 \mathrm{~min}$ and increased to $200{ }^{\circ} \mathrm{C}$ at a rate of $10{ }^{\circ} \mathrm{C} / \mathrm{min}$, then increased to 220 ${ }^{\circ} \mathrm{C}$ at a rate of $4{ }^{\circ} \mathrm{C} / \mathrm{min}$, which was kept for $15 \mathrm{~min}$. The carrier gas was hydrogen, and 
the pressure was 20.5 psi. Split flow was $120 \mathrm{~cm} / \mathrm{s}$. The identification of the fatty acid methyl esters was done by comparison of the retention times of the peaks in the sample with those of standard pure compounds (Sigma, St. Louis, MO, USA) and by spiking the sample with each standard individually. The quantification of individual fatty acids was based on the internal standard method, using heptadecanoic acid methyl ester (Sigma, St. Louis, MO, USA).

\section{Sodium and calcium determination}

An accurately weighed $(500 \mathrm{mg})$ sample of homogenized dried sausage was transferred into a high pressure digestion vessel and $7 \mathrm{ml}$ of sub-boiling nitric acid and 2 $\mathrm{ml}$ of tracepur hydrogen peroxide (Merck) was added. The teflon bombs were closed and placed into the microwave oven (Ethos Plus, Millestone s.r.l., Sorisole, Italy). A two steps optimized microwave digestion program consisting of $25-170{ }^{\circ} \mathrm{C}$ for $10 \mathrm{~min}$ and $170{ }^{\circ} \mathrm{C}$ for $10 \mathrm{~min}$, both at $1000 \mathrm{~W}$, was applied followed immediately by ventilation at room temperature. Digested samples were diluted to $50 \mathrm{ml}$ in a volumetric flask with ultrapure water. Three different portions of each sample were analyzed.

A Perkin-Elmer Model Analyst 800 atomic absorption spectrometer (Norwalk, CT, USA) equipped with flame atomizer was used. Sodium was determined by atomic emission at $589.0 \mathrm{~nm}$. Calcium measurements were performed by atomic absorption at $422.7 \mathrm{~nm}$, using hollow cathode lamp operated at $10 \mathrm{~mA}$ and bandwidth of $0.7 \mathrm{~nm}$. A high-sensitivity nebulizer and an air/acetylene flame with an oxidant and fuel flow of 17.0 and $2.0 \mathrm{ml} \mathrm{min}{ }^{-1}$ were used. To overcome potential anionic interferences when determining calcium, mainly strong phosphate interference, the final samples and standards was diluted to contain $1 \%$ (w/v) lanthanum (as chloride salt, $\mathrm{LaCl}_{3} .7 \mathrm{H}_{2} \mathrm{O}$; Merck). 
Sodium and calcium detection limits (LODs) were set at three times the standard deviation of the reagent blank, expressed in terms of wet weight sausage, corresponding to 0.07 and $0.02 \mathrm{mg} / 100 \mathrm{~g}$, respectively $(\mathrm{n}=6)$. Analytical recoveries $(101.6 \pm 1.2 \%$ and $102.3 \pm 1.1 \%$ for sodium and calcium, respectively) were determined from the SRM 1577b (NIST Bovine liver) in order to test the accuracy of the method. The found values (Na: $2.40 \pm 0.01 \mathrm{~g} / \mathrm{kg}, \mathrm{Ca}: 116.4 \pm 5.4 \mathrm{mg} / \mathrm{kg}, \mathrm{n}=6)$ showed acceptable good agreement with SRM certified values (Na: $2.42 \pm 0.06 \mathrm{~g} / \mathrm{kg}$, Ca: $116 \pm 4 \mathrm{mg} / \mathrm{kg}$ ). Details of measurements and analytical procedures are discussed elsewhere. ${ }^{30}$

Texture

A Universal TA-XT2i texture analyzer was used to conduct the texture profile analysis $^{18}$. Cubic samples $\left(1 \mathrm{~cm}^{3}\right)$ were compressed twice to $60 \%$ of their original height with a compression plate of $75 \mathrm{~mm}$ diameter. Force-time curves were recorded at a crosshead speed of $5 \mathrm{~mm} / \mathrm{s}$ and recording speed was also $5 \mathrm{~mm} / \mathrm{s}$. The Hardness parameter was obtained using the available computer software.

Color

For color measurement, samples were homogenized and introduced in a plate of $1 \mathrm{~cm}$ height. They were covered with a polyethylene film, with pressure to obtain a uniform, bubble-free surface. A colorimeter digital (Chromameter-2 CR-200, Minolta, Osaka, Japan) was used to obtain the reflectance spectra. Color coordinates were obtained with the conditions established by ${ }^{18}\left(\mathrm{CIE} \mathrm{L}^{*} \mathrm{a}^{*} \mathrm{~b}^{*}\right.$ system, angle $10^{\circ}$, illuminant D65). $\mathrm{L}^{*}, \mathrm{a}^{*}$ and $\mathrm{b}^{*}$ parameters indicate lightness, redness and yellowness, respectively. Chroma and Hue angles were also calculated:

$$
\text { Hue }=\operatorname{arctg}\left(\frac{b}{a}\right) \quad \text { Chroma }=\sqrt{a^{2}+b^{2}}
$$




\section{Sensory evaluation}

Two different types of sensory analysis were carried out at the end of the ripening process. In both tests, samples were presented sliced (about $2 \mathrm{~mm}$ thick), on a white plate, at room temperature, in normalized cabinets.

Two triangular tests were performed to determine the existence of perceptible sensory differences in odor, taste, juiciness, hardness and appearance between the control and the two modified formulations. 10 trained panelists participated in the sessions. Each panelist was presented with three samples, of which two were identical, and asked to indicate which sample differed from the others. The number of correct responses was determined and data shown in the table corresponded to the mean value obtained for each type of product by 10 members taking into account scores given by all panelists. According to the ${ }^{31}$, the difference between samples was significant if the number of correct answers was $6(p<0.05), 7(p<0.01)$ and $8(p<0.001)$.

A quantitative descriptive analysis (QDA) was used for evaluating color intensity, typical sausage taste, odor intensity, juiciness, saltiness and hardness. Three samples per batch were examined by 20 selected and trained panelists. A continue scale between 1 and 10 was used for evaluation. A value of 1.0 corresponded to the lowest intensity for each parameter and a value of 10.0 to the highest.

\section{Data Analysis}

Four batches were analyzed from each type of dry fermented sausage. Each parameter was determined four times in each batch. In tables, means \pm standard deviations are shown.

One-way ANOVA and a Tukey $b$ post hoc test were used to determine significant differences $(\mathrm{p}<0.05)$ among the three different types of sausages. The 
statistics package chosen for analysis was SPSS version 15.0 (SPSS inc. Chicago, Illinois, USA).

\section{RESULTS AND DISCUSSION}

Stability of products

The lower salt content of the new formulations and the inclusion of the emulsion had some effects on $\mathrm{a}_{\mathrm{w}}$ and $\mathrm{pH}$ at the end of the ripening process (Table 1). The first parameter increased 0.04 to 0.06 units in the new formulations, giving rise to a slight but significant higher $a_{\mathrm{w}}$ value. In the experimental design the partial substitution of $\mathrm{NaCl}$ by $\mathrm{CaAs}$ was made with the objective of getting an equivalent ionic strength, which obviously has minimized the modification of the $a_{w}$ of the final products. $p H$ showed a slight but significant decrease ( 0.24 units) only in the formulation with the lower salt reduction. In a previous work, a $\mathrm{pH}$ decrease was also found with a similar salt replacement. ${ }^{18}$ However, in this paper when the salt concentration decreased, no $\mathrm{pH}$ decrease was observed. So, it seems that there was no relationship between the reduction of salt and the observed $\mathrm{pH}$ decrease. In other papers dealing with $\mathrm{NaCl}$ reduction $^{32}$ and $\omega-3$ enrichment ${ }^{33}$ in dry fermented products, some effects had been observed in aw and $\mathrm{pH}$ evolution without affecting the safety of the products.

Despite the higher PUFA content of the new formulations (mainly $\omega-3$ fatty acids), the oxidative stability of the new formulations was guaranteed by the addition of antioxidants, as it can be observed in the TBARS results (Table 1). Values obtained at the end of the ripening process were low $(<0.15 \mathrm{mg} / \mathrm{kg})$ and similar among the three formulations $(p>0.05)$. Besides BHA, the additional CaAs present in the modified 
products might have contributed to maintain these low TBARS results, as this salt exerts antioxidant properties.

\section{Nutritional evaluation}

As it was expected due to the design of the new formulations, significant and beneficial changes were obtained in the amounts of $\mathrm{Na}$ and $\mathrm{Ca}$ compared to the control batches (Table 2). The $14 \mathrm{gSalt}$ formulation gave products with $38 \%$ sodium reduction and $400 \mathrm{mg}$ of $\mathrm{Ca} / 100 \mathrm{~g}$. According to the current EU food legislation, ${ }^{34,35}$ this product could receive the nutrition claims "reduced sodium" and "high calcium". These characteristics were similar to those obtained for dry fermented products with a traditional lipid profile developed in a previous work. ${ }^{18}$ The batches corresponding to $10 \mathrm{gSalt}$ formulation showed products with $50 \%$ of sodium reduction and $525 \mathrm{mg}$ $\mathrm{Ca} / 100 \mathrm{~g}$. The amount of ascorbate used did not reach the Upper Limit for this compound. ${ }^{36}$ These totally new formulations could receive the same nutrition claims, but obviously had additional nutritional advantages, without negative effects on the sensory properties, as it will be discussed below.

Regarding to the total fat content, the slight differences found in modified products compared to the control ones were due to the use of emulsions. Tables $3 \& 4$ show the differences in the fatty acid profile of the new formulation, getting similar results to those obtained in other works. ${ }^{7,37}$ Significant reductions of SFA and MUFA were observed, together with an increase of PUFA (Table 4). Also the $\omega-6 / \omega-3$ ratio was reduced nearly 8 fold, from 17.0 in the control to $2-2.3$ in the modified products, contributing to improve the nutritional properties of the new formulations.

Furthermore, the new formulations showed healthier lipid profiles and fulfill the requirements established by the EU Regulation" ${ }^{38}$ for the use of the health claim "source 
of omega-3 fatty acids", which are set in more than $0.3 \mathrm{~g} \alpha$-linolenic per $100 \mathrm{~g}$ and 100 kcal. Besides this, a normal portion of the new products $(50 \mathrm{~g})$ provide more than $53 \%$ of the labeling reference intake proposed for ALA by the Panel on Dietetic Products, Nutrition and Allergies. ${ }^{2}$

\section{Sensory properties}

Both the significant salt reductions and the modification on the lipid profile of the developed products may involve a clear influence in the sensory attributes of dry fermented sausages. To evaluate the consequences of the simultaneous modification of these compounds, instrumental analysis of color (Table 5) and texture were carried out. No significant differences in the lightness $\left(\mathrm{L}^{*}\right)$ were observed between the control formulation and the $14 \mathrm{gSalt}$ batches, suggesting that the modifications did not affect lightness. Previous works using oil emulsions as partial replacers of pork back fat did not modify $\mathrm{L}^{*}{ }^{9}$ However, a statistically significant decrease in $\mathrm{L}^{*}$ was found for the $10 \mathrm{gSalt}$ formulation, which could be related with the higher content of CaAs. ${ }^{39}$ found a correlation between high CaAs contents and low $\mathrm{L}^{*}$ values in marinated beef, concluding that $\mathrm{CaAs}$ could have a pro-oxidant effect over myoglobin that resulted in a slight darkening of the product. In our case, $a^{*}$ values did not show differences between control and modified products so it does not seem that myoglobin was oxidized. ${ }^{18}$ also found lower $\mathrm{L}^{*}$ values when a partial substitution of $\mathrm{NaCl}$ was carried out using $\mathrm{CaAs}$. Despite this modification, the values obtained for $\mathrm{L}^{*}$ were within the normal range for

this kind of products. ${ }^{9,40}$ Regarding chromaticity parameters, no differences in $\mathrm{a}^{*}, \mathrm{~b}^{*}$ or Chroma were detected in modified products compared to the control. Hue values, although slightly higher for the $10 \mathrm{gSalt}$ formulation, were also considered acceptable values for this kind of products. 
Different consequences of mineral modifications on instrumental textural properties of dry fermented sausages are described in the literature. ${ }^{18}$ found lower hardness values for salt reduced sausages compared to the control. ${ }^{41}$ reported formulations of dry fermented sausages that could be considered "source of calcium", using calcium lactate, gluconate and citrate for enriching these products. These authors pointed out the need of controlling the amounts of these salts to avoid an excess in hardness. In this work, the instrumental measure of hardness did not reveal significant differences among the three different formulations (Control: $1983 \mathrm{~g} ; 14 \mathrm{gSalt}: 2161 \mathrm{~g}$; $10 \mathrm{gSalt}: 2152 \mathrm{~g}$ ), pointing out the adequate rheological quality of the new formulations.

Figure 1 shows sensory scores obtained for the QDA test. Juiciness and color intensity received lower values, whereas juiciness and color intensity received lower values by trained panelists in modified products. Hardness, typical sausage taste and odor intensity were not affected by the modifications. Despite the lower salt content of modified products, no statistical differences were reported for saltiness perception among the three formulations, although a slight trend to lower scores was noticed in modified sausages. Effectively, whereas a score of 5.23 was given for control batches, a score of 4.53 was reported for the salt reduced products. According to ${ }^{13}$, the most promising sodium reduction strategy is to adapt the preference of consumers for saltiness by reducing sodium in small steps, and this preference can be modified by repeated exposure to low salt products. In this sense, the salt reduction could be industrially attempted by a progressive adaptation in order to ensure meeting the consumer's expectations. ${ }^{42}$ found that a reduction by $50 \%$ of the $\mathrm{NaCl}$ in fermented sausages can be successfully done without modifying acceptability, and concluded that there is a positive consumer attitude towards reduced sodium meat products. 
A second type of sensory test was carried out to evaluate differences at a consumer level, using a triangular test (Table 6). The comparison between the control batches versus $14 \mathrm{gSalt}$ batches revealed that panelists were not able to detect differences between the two formulations for any of the parameters evaluated $(p>0.05)$, pointing out theirs similarity. For juiciness, for instance, that received different scores in the QDA test, only 4 out of 10 panelists were able to distinguish correctly between the two samples, and only 2 out of 10 identified samples correctly according to their hardness. When the batches of $10 \mathrm{gSalt}$ were compared to the control ones, only appearance seemed to be different for both products, probably due to differences in color intensity, as the instrumental color evaluation and QDA analysis showed.

In conclusion, the strategy of combining a reduction in the salt content and a simultaneous modification in the lipid fraction of dry fermented sausages resulted in sensory viable products that could claim "reduced sodium", "high calcium" and "source of omega-3 fatty acids".

\section{ACKNOWLEDGEMENTS}

We thank the "Programa Consolider-Ingenio 2010 CARNISENUSA CSD200700016" and the "Proyecto AGL2008-01099/ALI" (Ministerio de Ciencia e Innovación), and the "Plan Investigador de la Universidad de Navarra" (PIUNA) for their contribution to the financial support of this work. I. Berasategi is also grateful to “Asociación de Amigos de la Universidad de Navarra” for the grants received. 


\section{REFERENCES}

1 Anderson M, de Benoist B, Darnton-Hill I and Delange F, editors. Iodine deficiency in Europe: A continuing public health problem. : World Health Organization (2007).

2 EFSA. Labelling reference intake values for $n-3$ and n- 6 polyunsaturated fatty acids. EFSA J 1176:1-11 (2009a).

3 He FJ, Jenner K, MacGregor GA. WASH-World Action on Salt and Health. Kidney Int 78(8): 745-753 (2010).

4 Doyle ME and Glass KA. Sodium reduction and its effect on food Safety, food Quality, and human health. Compr Rev Food Sci Food Saf 9(1) :44-56 (2010).

5 McAfee AJ, McSorley EM, Cuskelly GJ, Moss BW, Wallace JMW, Bonham MP, et al. Red meat consumption: An overview of the risks and benefits. Meat Sci 84(1): 1-13 (2010).

6 Weiss J, Gibis M, Schuh V and Salminen H. Advances in ingredient and processing systems for meat and meat products. Meat Sci 86(1): 196-213 (2010).

7 Ansorena D and Astiasarán I. The use of linseed oil improves nutritional quality of the lipid fraction of dry-fermented sausages. Food Chem 87(1): 69-74 (2004b).

8 Valencia I, O'Grady MN, Ansorena D, Astiasarán I and Kerry JP. Enhancement of the nutritional status and quality of fresh pork sausages following the addition of linseed oil, fish oil and natural antioxidants. Meat Sci 80(4): 1046-1054 (2008).

9 García-Íñiguez de Ciriano M, Larequi E, Rehecho S, Calvo MI, Cavero RY, NavarroBlasco Í, et al. Selenium, iodine, $\omega-3$ PUFA and natural antioxidant from Melissa officinalis L.: A combination of components from healthier dry fermented sausages formulation. Meat Sci 85(2): 274-279 (2010b).

10 Berasategi I, Legarra S, García-Íñiguez de Ciriano M, Rehecho S, Calvo MI, Cavero RY, et al. "High in omega-3 fatty acids" bologna-type sausages stabilized with an aqueous-ethanol extract of Melissa officinalis. Meat Sci 88(4): 705-711 (2011).

11 Pérez-Juan M, Flores M and Toldra F. Effect of ionic strength of different salts on the binding of volatile compounds to porcine soluble protein extracts in model systems. Food Res Int 40(6): 687-693 (2007).

12 Taormina PJ. Implications of Salt and Sodium Reduction on Microbial Food Safety. Crit Rev Food Sci Nutr 50(3): 209-227 (2010).

13 Dötsch M, Busch J, Batenburg M, Liem G, Tareilus E, Mueller R, et al. Strategies to Reduce Sodium Consumption: A Food Industry Perspective. Crit Rev Food Sci Nutr 49(10): 841-851 (2009). 
14 Gimeno O, Astiasarán I and Bello J. Influence of partial replacement of $\mathrm{NaCl}$ with $\mathrm{KCl}$ and $\mathrm{CaCl} 2$ on texture and color of dry fermented sausages. J Agric Food Chem 47(3): 873-877 (1999).

15 Fulladosa E, Serra X, Gou P and Arnau J. Effects of potassium lactate and high pressure on transglutaminase restructured dry-cured hams with reduced salt content. Meat Sci 82(2):2 13-218 (2009).

16 Armenteros M, Aristoy M, Barat JM and Toldrá F. Biochemical and Sensory Properties of Dry-Cured Loins as Affected by Partial Replacement of Sodium by Potassium, Calcium, and Magnesium. J Agric Food Chem 57(20): 9699-9705 (2009).

17 Verma AK, Sharma BD and Banerjee R. Effect of sodium chloride replacement and apple pulp inclusion on the physico-chemical, textural and sensory properties of low fat chicken nuggets. LWT Food Sci Tech 43(4): 715-719 (2010).

18 Gimeno O, Astiasarán I and Bello J. Calcium ascorbate as a potential partial substitute for $\mathrm{NaCl}$ in dry fermented sausages: effect on colour, texture and hygienic quality at different concentrations. Meat Sci 57(1): 23-29 (2001).

19 Lee JRR, Kwack SC, Jung JD, Hah YJ, Park KH, Cho HS, et al. Effects of replacement sodium chloride on the quality characteristices of emulsion-type sausages. J Anim Sci Technol 47(6): 1009-1016 (2005).

20 Cai J, Zhang Q, Wastney M and Weaver C. Calcium Bioavailability and kinetics of calcium ascorbate and calcium acetate in rats. Exp Biol Med 229(1): 40-45 (2004).

21 Heaney RP and Barger-Lux MJ. Calcium in nutrition and prevention of disease. Food Nutrition News 63(2): 7-10 (1991).

22 López-López I, Cofrades S, Yakan A, Solas MT and Jiménez-Colmenero F. Frozen storage characteristics of low-salt and low-fat beef patties as affected by Wakame addition and replacing pork backfat with olive oil-in-water emulsion. Food Res Int 43(5): 1244-1254 (2010).

23 Totosaus A and Pérez-Chabela ML. Textural properties and microstructure of lowfat and sodium-reduced meat batters formulated with gellan gum and dicationic salts. LWT Food Sci Tech 42(2): 563-569 (2009).

24 Muguerza E, Gimeno O, Ansorena D, Bloukas JG and Astiasarán I. Effect of replacing pork backfat with pre-emulsified olive oil on lipid fraction and sensory quality of Chorizo de Pamplona - a traditional Spanish fermented sausage. Meat Sci 59(3): 251-258 (2001).

25 AOAC. Ash of meat. 920.153. In: Horwitz W, editor. Official method of analysis. 17th ed. Gaithersburg, Maryland: Association of Official Analytical Chemists p. 4-5 (2002d). 
26 AOAC. Fat (crude) or ether extract in meat. 960.39. In: Horwitz W, editor. Official method of analysis. 17th ed. Gaithersburg, Maryland: Association of Official Analytical Chemists p. 12-13 (2002b).

27 Tarladgis BG, Pearson AM and Dugan LR, Jr. Chemistry of 2-thiobarbituric acid test for determination of oxidative rancidity in foods II. Formation of TBA-malonaldehyde complex without acid-heat treatment. J Sci Food Agric 15(9): 602-607 (1964).

28 Folch J, Lees M, Stanley GHS. A simple method for the isolation and purification of total lipides from animal tissues. J Biol Chem 226(1): 497-509 (1957).

29 AOAC. Methyl esteres of fatty acids in oils and fats. 969.33. In: Horwitz W, editor. Official methods of analysis. 17th ed. Gaithersburg, Maryland: Association of Official Analytical Chemists p. 19-20 (2002e).

30 Sola-Larrañaga C, Navarro-Blasco Í. Chemometric analysis of minerals and trace elements in raw cow milk from the community of Navarra, Spain. Food Chem 112(1): 189-196 (2009).

31 UNE 87-006-92. Norma Española. Metodología Prueba Triangular (1992).

32 Campagnol PCB, Santos BAd, Morgano MA, Terra NN, Pollonio MAR. Application of lysine, taurine, disodium inosinate and disodium guanylate in fermented cooked sausages with 50\% replacement of $\mathrm{NaCl}$ by KCl. Meat Sci 87(3): 239-243 (2011).

33 Hoz L, D'Arrigo M, Cambero MI, Ordóñez JA. Development of an n-3 fatty acid and $\alpha$-tocopherol enriched dry fermented sausage. Meat Sci 67(3): 485-495 (2004).

34 EU regulation (EC). Corrigendum to Regulation (EC) Num. 1924/2006 of the European Parliament and of the Council of 20 December 2006 on nutrition and health claims made on foods. Off J Eur Union 2007 L(12): 3-18 (2007).

35 EU regulation (EC). Commission Directive 2008/100/EC of 28 October 2008 amending Council Directive 90/496/EEC on nutrition labelling for foodstuffs as regards recommended daily allowances, energy conversion factors and definitions. Off $\mathrm{J}$ Eur Union 2008 L(285): 9-12 (2008).

36 Food and Nutrition Board, Institute of Medicine. Vitamin C. Reference Dietary Intakes for Vitamin C, Vitamin E, Selenium and Carotenoids Washington, DC: National Academies Press (2000).

37 García-Íñiguez de Ciriano M, García-Herreros C, Larequi E, Valencia I, Ansorena D, Astiasarán I. Use of natural antioxidants from lyophilized water extracts of Borago officinalis in dry fermented sausages enriched in $\omega-3$ PUFA. Meat Sci 83(2): 271-277 (2009).

38 EU regulation (EC). Commission Regulation (EU) Num. 116/2010 of 9 February 2010 amending Regulation (EC) No 1924/2006 of the European Parliament and of the Council with regard to the list of nutrition claims. Off J Eur Union 2010 L(37):16-18 (2010). 
39 Lawrence TE, Dikeman ME, Hunt MC, Kastner CL, Johnson DE. Effects of calcium salts on beef longissimus quality. Meat Sci 64(3): 299-308 (2003).

40 Gimeno O, Ansorena D, Astiasarán I, Bello J. Characterization of chorizo de Pamplona: instrumental measurements of colour and texture. Food Chem 69(2): 195$200(2000)$.

41 Selgas MD, Salazar P, García ML. Usefulness of calcium lactate, citrate and gluconate for calcium enrichment of dry fermented sausages. Meat Sci 82(4): 478-480 (2009).

42 Guàrdia MD, Guerrero L, Gelabert J, Gou P, Arnau J. Consumer attitude towards sodium reduction in meat products and acceptability of fermented sausages with reduced sodium content. Meat Sci 73(3): 484-490 (2006). 
Table 1. Technological parameters and TBARS values (mg Malondialdehyde (MDA)/kg of product).

\begin{tabular}{lccc}
\hline & Control & 14gSalt & 10gSalt \\
\hline aw & $0.81 \pm 0.01 \mathrm{a}$ & $0.85 \pm 0.01 \mathrm{~b}$ & $0.87 \pm 0.01 \mathrm{~b}$ \\
pH & $5.22 \pm 0.03 \mathrm{~b}$ & $4.98 \pm 0.01 \mathrm{a}$ & $5.21 \pm 0.07 \mathrm{~b}$ \\
TBARS & $0.13 \pm 0.04$ & $0.14 \pm 0.01$ & $0.15 \pm 0.03$ \\
\hline
\end{tabular}

Results are expressed as mean \pm standard deviation. For each parameter, different letters denote significant differences among formulations $(\mathrm{p}<0.05)$. 
Table 2. Fat and mineral content (ash, sodium and calcium).

\begin{tabular}{lccc}
\hline & Control & 14gSalt & 10gSalt \\
\cline { 1 - 4 } Fat (g/100 g sausage) & $32.96 \pm 1.20 \mathrm{~b}$ & $31.25 \pm 1.35 \mathrm{ab}$ & $30.48 \pm 0.24 \mathrm{a}$ \\
Ash (g/100 g sausage) & $5.76 \pm 0.03 \mathrm{~b}$ & $4.36 \pm 0.70 \mathrm{a}$ & $4.36 \pm 0.24 \mathrm{a}$ \\
\cline { 1 - 1 } & & & \\
\cline { 1 - 1 } Na (g/100 g sausage) & $1.87 \pm 0.02 \mathrm{c}$ & $1.16 \pm 0.03 \mathrm{~b}$ & $0.94 \pm 0.07 \mathrm{a}$ \\
Ca (mg/100 g sausage) & $86.8 \pm 19.6 \mathrm{a}$ & $399.9 \pm 13.7 \mathrm{~b}$ & $525.7 \pm 13.3 \mathrm{c}$ \\
\hline
\end{tabular}

Results are expressed as mean \pm standard deviation. Different letters within a row denote significant differences among formulations $(\mathrm{p}>0.05)$. 
Table 3. Fatty acid profile of the three formulations (g FA/100 g fat).

\begin{tabular}{|c|c|c|c|}
\hline & Control & 14gSalt & 10gSalt \\
\hline Caprilic C8:0 & $0.14 \pm 0.00$ & $0.12 \pm 0.00$ & $0.13 \pm 0.01$ \\
\hline Capric C10:0 & $0.15 \pm 0.00$ & $0.15 \pm 0.00$ & $0.16 \pm 0.02$ \\
\hline Lauric C12:0 & $0.08 \pm 0.00$ & $0.07 \pm 0.00$ & $0.08 \pm 0.01$ \\
\hline Myristic C14:0 & $1.14 \pm 0.00 \mathrm{c}$ & $1.04 \pm 0.01 \mathrm{a}$ & $1.07 \pm 0.02 \mathrm{~b}$ \\
\hline Palmitic C16:0 & $22.45 \pm 0.02 b$ & $20.06 \pm 0.03 \mathrm{a}$ & $20.06 \pm 0.04 \mathrm{a}$ \\
\hline t-Palmitoleic C16:1t & $0.43 \pm 0.01 b$ & $0.32 \pm 0.00 \mathrm{a}$ & $0.31 \pm 0.01 \mathrm{a}$ \\
\hline Palmitoleic C16:1 & $1.92 \pm 0.01 \mathrm{~b}$ & $1.69 \pm 0.02 \mathrm{a}$ & $1.68 \pm 0.03 \mathrm{a}$ \\
\hline Stearic C18:0 & $11.51 \pm 0.02 \mathrm{~b}$ & $10.75 \pm 0.09 \mathrm{a}$ & $10.76 \pm 0.18 \mathrm{a}$ \\
\hline Elaidic C18:1t & $0.35 \pm 0.00 \mathrm{~b}$ & $0.27 \pm 0.02 \mathrm{a}$ & $0.26 \pm 0.00 \mathrm{a}$ \\
\hline 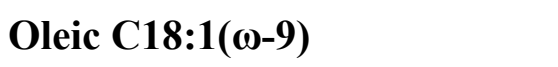 & $39.60 \pm 0.04 \mathrm{c}$ & $38.31 \pm 0.05 b$ & $37.09 \pm 0.20 \mathrm{a}$ \\
\hline Vaccenic C18:1( $\omega-7)$ & $3.09 \pm 0.02 \mathrm{c}$ & $2.83 \pm 0.01 \mathrm{~b}$ & $2.76 \pm 0.02 \mathrm{a}$ \\
\hline$t$-Linoleic C18:2t & $0.09 \pm 0.00 \mathrm{~b}$ & $0.08 \pm 0.00 \mathrm{a}$ & $0.08 \pm 0.00 \mathrm{a}$ \\
\hline c-t linoleic C18:1c,1t & $0.04 \pm 0.00 \mathrm{~b}$ & $0.04 \pm 0.00 \mathrm{ab}$ & $0.04 \pm 0.00 \mathrm{a}$ \\
\hline t-c linoleic C18:1t,1c & $0.09 \pm 0.00 \mathrm{~b}$ & $0.08 \pm 0.00 \mathrm{a}$ & $0.08 \pm 0.00 \mathrm{a}$ \\
\hline 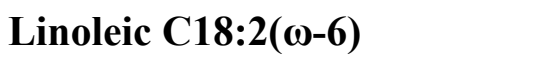 & $16.21 \pm 0.01 \mathrm{~b}$ & $15.52 \pm 0.07 \mathrm{a}$ & $15.68 \pm 0.14 \mathrm{a}$ \\
\hline Arachidic C20:0 & $0.04 \pm 0.00 \mathrm{a}$ & $0.07 \pm 0.00 \mathrm{~b}$ & $0.06 \pm 0.02 b$ \\
\hline 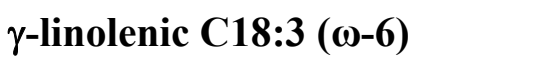 & $0.04 \pm 0.00 \mathrm{~b}$ & $0.03 \pm 0.00 \mathrm{a}$ & $0.03 \pm 0.00 \mathrm{a}$ \\
\hline Eicosanoic C20:1( $(\omega-9)$ & $0.74 \pm 0.00 \mathrm{~b}$ & $0.63 \pm 0.01 \mathrm{a}$ & $0.64 \pm 0.02 \mathrm{a}$ \\
\hline$\alpha$-linolenic C18:3( $\omega-3)$ & $0.87 \pm 0.01 \mathrm{a}$ & $6.89 \pm 0.08 b$ & $8.00 \pm 0.22 \mathrm{c}$ \\
\hline Eicosadienoic C20:2 ( $\omega-6)$ & nd & nd & nd \\
\hline Behenic C22:0 & $0.09 \pm 0.00 \mathrm{~b}$ & $0.08 \pm 0.00 \mathrm{ab}$ & $0.08 \pm 0.00 \mathrm{a}$ \\
\hline Brasidic C20:1t & $0.01 \pm 0.00 \mathrm{a}$ & $0.01 \pm 0.00 \mathrm{~b}$ & $0.01 \pm 0.00 \mathrm{~b}$ \\
\hline Erucic C22:1 & $0.11 \pm 0.00 \mathrm{c}$ & $0.11 \pm 0.00 \mathrm{~b}$ & $0.10 \pm 0.00 \mathrm{a}$ \\
\hline Eicosatrienoic C20:3( $\omega-3)$ & nd & nd & nd \\
\hline 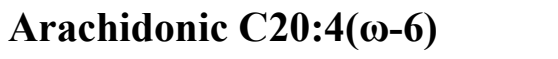 & $0.38 \pm 0.01 \mathrm{a}$ & $0.42 \pm 0.00 \mathrm{~b}$ & $0.42 \pm 0.01 \mathrm{~b}$ \\
\hline Eicosapentaenoic C20:5( $\omega-6)$ & $0.06 \pm 0.00 \mathrm{~b}$ & $0.05 \pm 0.00 \mathrm{a}$ & $0.05 \pm 0.00 \mathrm{a}$ \\
\hline 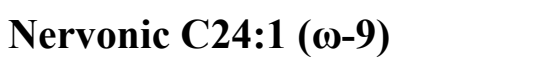 & $0.13 \pm 0.00 \mathrm{~b}$ & $0.12 \pm 0.00 \mathrm{a}$ & $0.11 \pm 0.00 \mathrm{a}$ \\
\hline Docosapentaenoic C22:5 ( $\omega-6)$ & $0.10 \pm 0.00$ & $0.10 \pm 0.00$ & $0.10 \pm 0.01$ \\
\hline Lignoceric C24:0 & $0.10 \pm 0.00 \mathrm{a}$ & $0.11 \pm 0.00 \mathrm{~b}$ & $0.10 \pm 0.00 \mathrm{a}$ \\
\hline Docosapentaenoic C22:5 ( $\omega-3)$ & nd & nd & nd \\
\hline 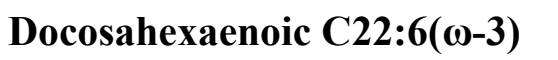 & $0.05 \pm 0.00$ & $0.06 \pm 0.00$ & $0.06 \pm 0.00$ \\
\hline
\end{tabular}

Fatty acids are expressed in $\mathrm{g} / 100 \mathrm{~g}$ of fat as mean \pm standard deviation. For each fatty acid, different letters denote significant differences among formulations $(\mathrm{p}<0.05)$. nd.: non detected. 
Table 4. Fatty acid fractions and relations (g FFA/100 g of product).

\begin{tabular}{lccc}
\hline & Control & 14gSalt & 10gSalt \\
\hline SFA & $11.73 \pm 0.01 \mathrm{c}$ & $10.11 \pm 0.03 \mathrm{~b}$ & $9.87 \pm 0.06 \mathrm{a}$ \\
MUFA & $15.03 \pm 0.01 \mathrm{c}$ & $13.65 \pm 0.01 \mathrm{~b}$ & $12.92 \pm 0.06 \mathrm{a}$ \\
PUFA & $5.84 \pm 0.01 \mathrm{a}$ & $7.21 \pm 0.05 \mathrm{~b}$ & $7.42 \pm 0.11 \mathrm{c}$ \\
$\mathbf{\omega - 3}$ & $0.32 \pm 0.01 \mathrm{a}$ & $2.19 \pm 0.02 \mathrm{~b}$ & $2.47 \pm 0.07 \mathrm{c}$ \\
$\mathbf{\omega - 6}$ & $5.51 \pm 0.01 \mathrm{c}$ & $5.02 \pm 0.02 \mathrm{~b}$ & $4.95 \pm 0.05 \mathrm{a}$ \\
$\mathbf{\omega - 6 / \omega - 3}$ & $16.99 \pm 0.29 \mathrm{~b}$ & $2.30 \pm 0.02 \mathrm{a}$ & $2.00 \pm 0.04 \mathrm{a}$ \\
PUFA/SFA & $0.50 \pm 0.00 \mathrm{a}$ & $0.71 \pm 0.01 \mathrm{~b}$ & $0.75 \pm 0.02 \mathrm{c}$ \\
PUFA + MUFA/SFA & $1.78 \pm 0.00 \mathrm{a}$ & $2.06 \pm 0.01 \mathrm{~b}$ & $2.06 \pm 0.02 \mathrm{~b}$ \\
trans & $0.33 \pm 0.00 \mathrm{c}$ & $0.25 \pm 0.01 \mathrm{~b}$ & $0.24 \pm 0.00 \mathrm{a}$ \\
\hline
\end{tabular}

Fatty acids fractions are expressed in $\mathrm{g} / 100 \mathrm{~g}$ of fat as mean \pm standard deviation. For each parameter, different letters denote significant differences among types of formulations $(\mathrm{p}<0.05)$. 
Table 5. Instrumental color CIEL*a*b* evaluation analysis.

\begin{tabular}{lccc}
\hline & Control & 14gSalt & 10gSalt \\
\hline $\mathbf{L}^{*}$ & $45.70 \pm 0.36 \mathrm{~b}$ & $45.61 \pm 2.19 \mathrm{~b}$ & $43.62 \pm 1.07 \mathrm{a}$ \\
$\mathbf{a} *$ & $20.58 \pm 1.01 \mathrm{a}, \mathrm{b}$ & $21.95 \pm 2.68 \mathrm{~b}$ & $20.27 \pm 1.63 \mathrm{a}$ \\
$\mathbf{b *}$ & $15.08 \pm 1.28$ & $16.51 \pm 2.83$ & $16.13 \pm 1.82$ \\
Chroma & $25.52 \pm 1.56$ & $27.49 \pm 3.83$ & $25.91 \pm 2.40$ \\
Hue & $36.17 \pm 1.08 \mathrm{a}$ & $36.76 \pm 1.60 \mathrm{a}$ & $38.44 \pm 1.07 \mathrm{~b}$ \\
\hline *Results are expressed as mean \pm standard deviation. For each parameter, \\
different letters denote significant differences among types of formulations \\
$(\mathrm{p}<0.05)$.
\end{tabular}


Table 6. Scores of Triangular sensory analysis.

\begin{tabular}{cccccc}
\hline & \multicolumn{5}{c}{ Control vs. 14gSalt } \\
\cline { 2 - 6 } & Odor & Taste & Juiciness & Hardness & Appearance \\
\hline Correct replies & $6 \mathrm{~ns}$ & $5 \mathrm{~ns}$ & $4 \mathrm{~ns}$ & $2 \mathrm{~ns}$ & $4 \mathrm{~ns}$ \\
Incorrect replies & 4 & 5 & 6 & 8 & 6 \\
\hline & \multicolumn{5}{c}{ Control vs. 10gSalt } \\
\cline { 2 - 6 } & Odor & Taste & Juiciness & Hardness & Appearance \\
\hline Correct replies & $3 \mathrm{~ns}$ & $6 \mathrm{~ns}$ & $5 \mathrm{~ns}$ & $5 \mathrm{~ns}$ & $7 *$ \\
Incorrect replies & 7 & 4 & 5 & 5 & 3 \\
\hline For $\mathrm{n}=10$, the difference between samples was significant if the number of correct \\
answers was $7(*=\mathrm{p}<0.05), 8(* *=\mathrm{p}<0.01)$ and $9(* * *=\mathrm{p}<0.001)$. ns: not significant.
\end{tabular}

